\title{
Politik Hukum Industrialisasi di Indonesia Dalam Tinjauan Historis
}

\author{
Syahriza Alkohir Anggoro \\ Program Magister Ilmu Hukum \\ Fakultas Hukum, Universitas Brawijaya \\ Author's email rizarathustra@yahoo.co.id \\ Iqbal Fajar Dwiranda \\ Program Magister Ilmu Politik \\ Fakultas Ilmu Sosial dan Ilmu Politik, Universitas Airlangga \\ Author's emaildwiranda47@gmail.com
}

DOI: $10.23917 /$ jjr.v9i2.8734

\section{Submission \\ Track: \\ Received: \\ 29 Agustus 2019 \\ Final Revision:}

13 Desember 2019

Available online:

17 Januari 2020

Corresponding

Author:

Syahriza Alkohir Anggoro rizarathustra@yahoo.co.id

\section{ABSTRAK}

Tujuan: Artikel ini menganalisis dinamika kepentingan ekonomi-politik yang melatarbelakangi lahirnya UU No 5 Tahun 1984 tentang Perindustrian dibawah periode kekuasaan rezim Orde Baru.

Metodologi: Artikel ini merupakan artikel hukum non-doktrinal yang menggunakan metode penelitian hukum sosio-legal. Bahan hukum di sajikan dengan pendekatan ekonomi politik hukum (political economy of law) untuk mengidentifikasi kepentingan yang melatarbelakangi pembentukan produk hukum.

Temuan: Pembentukan UU No 5 Tahun 1984 tentang Perindustrian tidak dapat dilepaskan dari pentingnya sektor perindustrian sebagai arena pertarungan yang kompleks yang melibatkan berbagai kepentingan kelas penguasa, pemikiran teknokrat serta elite kongsi bisnis.

Kegunaan: Artikel ini menawarkan penjelasan alternatifkemunculan UU No 5 Tahun 1984 tentang Perindustrian dari sudut pandang interdisipliner.

Kebaruan/Orisinalitas: Konfigurasi politik, perbedaan preferensi ideologis dan perubahan sosial yang berlangsung di masa Orde Baru sangat menentukan arah politik hukum UU No 5 Tahun 1984 tentang Perindustrian yang dimaksudkan untuk menciptakan kondisi-kondisi yang memungkinkan industri domestik dapat mandiri dalam memperluas kegiatan 
industrinya serta mengurangi ketergantungan Indonesia terhadap investasi asing.

Keywords: Politik Hukum, Industrialisasi, Sejarah Hukum, dan Penelitian Hukum Interdisipliner

\section{PENDAHULUAN}

UU No 5 Tahun 1984 tentang Perindustrian (selanjutnya disebut UU Perindustrian) merupakan salah satu produk hukum di bidang ekonomi yang penting sepanjang periode kekuasaan Orde Baru. Tekad untuk menjadikan rezim Orde Baru sebagai rezim pembangunan telah diakui banyak pihak yang tidak mungkin bisa terlaksana tanpa kegiatan ekonomi yang nyata serta kemampuan dan kontrol atas alokasi sumber daya dari para pelaku ekonomi. Oleh karenanya tatkala rezim Orde Baru mengkonsolidasikan diri pada tahun 1966/1967, 'persoalan pembangunan telah menjadi perhatian serius yang harus diberikan sebuah kepastian kemana arah pembangunan itu dimasa mendatang' (Wijoyo Nitisastro, 2010). Berbeda dari masa sebelumnya, persoalan pembangunan semata-mata direduksi menjadi persoalan politis yang terpusat pada Presiden dengan slogan-slogan anti imperialisme revolusioner (Kian Wie, 2012). Prinsip ekonomi terpimpin yang menyatakan bahwa hukum adalah sarana untuk menuntaskan revolusi yang belum selesai dimasa Orde Baru kini tidak bisa lagi di terima. Sebagai gantinya — dalam rangka mengejar ketertinggalan pembangunan yang telah dicapai oleh negara-negara industri melalui program industrialisasi besarbesaran-rezim Orde Baru meletakkan hukum sebagai sarana untuk melaksanakan pembangunan. Tidaklah mengherankan jika kemudian sektor perindustrian sebagai sektor produksi yang penting dalam pembangunan telah mendapat sorotan sejak awal.

Bagi mereka yang mengamati kemunculan rezim Orde Baru, dengan cepat akan mengkaitkan agenda pembangunan yang di usung rezim dengan sederet peraturan perundangundangan di bidang ekonomi yang muncul diawal-awal kekuasaan rezim, diantaranya UU No 1 Tahun 1967 tentang Penanaman Modal Asing, UU No 8 Tahun 1968 tentang Penanaman Modal Dalam Negeri, UU No 5 Tahun 1967 tentang Pokok-Pokok Kehutanan, UU No 11 Tahun 1967 tentang Ketentuan Pokok Pertambangan, Perppu No 6 Tahun 1969 tentang Perusahaan Ne gara dan UU No 8 Tahun 1971 tentang Minyak dan Gas Bumi, disusul kemudian penerbitan Rencana Pembangunan Lima Tahun I pada tahun 1969 yang menegaskan kembali peranan hukum dalam pembangunan nasional. Komitmen terhadap 
pembangunan ini tidak dapat berjalan tanpa adanya kepercayaan bahwa prinsip-prinsip hukum tetap ditaati di Indonesia dan bahwasanya para pemegang tampuk kekuasaan diIndonesia juga masih tetap menjamin kepastian hukum (Wignjosoebroto, 2014: 209).

Sebagai produk perjuangan nasionalis yang tahun 1945, Pasal 33 UUD 1945 mengamanatkan perekonomian disusun berdasarkan atas asas kekeluargaan dan cabang produksi dan sumber daya alam yang penting bagi negara dan yang menguasai hajat hidup orang banyak dikuasai oleh negara. Memang, pasal ini menjadi semacam refleksi panjang dari gerakan nasionalis pra kemerdekaan yang bisa ditemukan jejak klimaksnya dalam risalah sidang konstitusi (Moh. Hatta, 1980 dan; Moh. Yamin, 1959). Setiap orang yang membaca risalah sidang tersebut dengan segera akan sampai pada kesimpulan bahwa betapa ideal-ideal sosialisme sangat mengakar pada alam pikiran para penyusun konstitusi (Daniel S Lev, 1966: 70). Namun demikian, konsep kapitalisme liberalisme yang dianggap inkonstitusional itu justru menjadi masalah tatkala konsep utama sistem ekonomi liberal seperti promosi investasi asing dan perlindungan kepemilikan mesti diadopsi untuk mencegah kemerosotan ekonomi lebih jauh. Oleh karenanya ketika rezim Orde Baru mengkonsolidasikan kekuasaannya pada pertengahan 60an, unsur teknokrasi telah memainkan peran penting untuk membungkus konsep-konsep tadi dengan wajah baru.

Akan tetapi, keberpihakan pada sistem ekonomi liberal yang bisa di temukan dalam banyak produk hukum bidang ekonomi sepanjang periode kekuasaan Orde Baru pada kenyataannya tidak se-monolitik yang dibayangkan. Kepentingan politik, kontestasi ideologi, perubahan sosial, dan peristiwa-peristiwa penting yang menentukan kemana arah perkembangan masyarakat senantiasa mewarnai serta melatarbelakangi dan menjadi pertimbangan bagi munculnya produk hukum bidang ekonomi pada waktu tertentu. Fenomena menonjolnya fungsi instrumental hukum sebagai sarana pembangunan yang sarat akan kepentingan tertentu lebih terasa bila dibandingkan fungsi-fungsi lainnya, bahkan dapat dilihat dari pertumbuhan pranata hukum, nilai dan prosedur perundang-undangan dan birokrasi penegak hukum yang bukan hanya mencerminkan hukum sebagai saranapembangunan melainkan juga menjadi penopang tangguh struktur politik, ekonomi dan sosial (Mahfud MD, 1995: 12). Dalam konteks inilah, menyepakati penggunaan istilah politik hukum berarti menyepakati bahwa hukum tidak bisa dilepaskan dari aspek politik, bahkan aspek ideologi, sosial, ekonomi yang luas yang mempengaruhi pilihan kebijakan dalam proses pembentukan hukum (Alkohir, 2019) 


\section{METODOLOGI PENELITIAN}

Artikel ini membahas berbagai perubahan politik, sosial dan ekonomi yang mempengaruhi kemunculan UU Perindustrian pada pertengahan periode kekuasaan Orde Baru. Artikel ini menggunakan metode penelitian hukum sosio-legal yang bertumpu pada silogisme induktif yang menekankan eksplanasi tentang ada-tidaknya hubungan (baik kausal maupun korelatif) antara berbagai variabel sosio-hukum (Wignjosoebroto, 2013: 124). Bahan hukum di sajikan dengan pendekatan ekonomi politik hukum (political economy of law) untuk mengidentifikasi kepentingan yang melatarbelakangi pembentukan produk hukum (Mattei dan Haskell, 2015).

\section{PEMBAHASAN}

\section{Orde Baru, Nasionalisme Ekonomi dan Industrialisasi}

Sepanjang periode kekuasaan Orde Baru, Pemerintah telah memimpin industrialisasi yang mengesankan melalui kombinasi antara pinjaman luar negeri, investasi asing, dan belakangan pendapatan negara dari sektor migas pada dekade 70an. Bangkitnya industrialisasi tersebut tidak terlepas dari berbagai produk hukum yang telah berkontribusi besar dalam menyelamatkan Indonesia dari stagnasi krisis ekonomi. Pasal 25TAP MPRS No XIII/MPRS/1966 tentang Pembaharuan Kebijakan Ekonomi, Keuangan dan Pembangunan telah memprioritaskan bidang pertanian, prasarana dan industri ekstraksi sumber daya sebagai prioritas pembangunan jangka panjang disusul kemudian Repelita I yang memberi prioritas industrialisasi pertanian. Meskipun Repelita I telah berkomitmen terhadap industrialisasi bidang pertanian, keterpisahan antara sektor yang menjadi prioritas Repelita di satu pihak dan sektor industri ekstraksi sumber daya melalui investasi asing, swasta nasional dan perusahaan negara, adalah hal yang tidak bisa ditutup-tutupi. Oleh karenanya industrialisasi yang terjadi sepanjang periode Repelita I dan pola yang sama dilanjutkan oleh Repelita II, sektor-sektor industri tadi justru tidak saling terintegrasi satu sama lain. Keterpisahan inilah yang menjadi sasaran kritik kalangan teknokrat nasionalis seperti A.R. Soehoed yang menyatakan bahwa 'kemajuan dalam industrialisasi selama Repelita I dan II hanya memperlebar, bukan memperdalam struktur industri. Industri bertambah banyak tetapi saling tumbuh terlepas satu sama lain, dan malahan dalam beberapa kasus saling bersaing dan tidak saling memperkokoh' (Kian Wie, 1994: 21). 
Proses industrialisasi yang terjadi di Indonesia tidak bisa terlepas dari peranan kaum teknokrat, yang pikiran-pikiran cemerlangnya banyak mengilhami kebijakan Pemerintah. Krisis ekonomi, inflasi mencapai $600 \%$, pengangguran dan defisit investasi adalah prioritas utama yang mesti diselesaikan, sekaligus menjadi prakondisi bagi kaum teknokrat liberal dalam merumuskan kebijakan industrialisasi yang berpihak pada pelaku ekonomi berskala besar. Investasi industri modal asing lebih diutamakan ketimbang investasi industri dalam negeri berskala menengah dan kecil karena memberi kontribusi lebih besar atas peningkatan produktivitas dalam negeri dan penyerapan surplus pengangguran. Disamping memastikan bahwa investasi industri besar akan memperoleh perlindungan dan kepastian, iklim persaingan usaha yang keras akan menyeleksi secara cermat industri dalam negeri yang efisien dan kompetitif.

Sekalipun pandangan kaum teknokrat liberal ini secara umum bisa diterima lantaran dikehendaki penguasa karena bisa menciptakan angka pertumbuhan yang di inginkan, banyak para pihak berpandangan bahwa pikiran-pikiran seperti itu tidak lazim bagi negara yang memiliki pengalaman pahit atas eksploitasi modal asing. Keengganan para teknokrat liberal dalam memberikan perlakuan khusus pada industri dalam negeri yang korup dan inefisien sebagaimana pengalaman perekonomian Indonesia tahun 50 dan 60an akan menghambat perbaikan dan mengulang krisis ekonomi (Robison, 2012: 10). Guna mencegah jatuh ke lubang yang sama, pencabutan perlakuan khusus kepada industri dalam negeri dan membiarkannya bersaing secara bebas dengan industri berbasis kapital asing akan membuat industri dalam negeri lebih berdaya saing. Rezim Orde Baru melihat pandangan ini beresiko secara politis karena akan mengancam basis dukungan para industrialis dalam negeri dan akan sangat berbahaya bagi pembangunan ekonomi jangka panjang. Masih mengakarnya pandangan perlunya intervensi negara atas pembangunan industri nasional menjadikan usulan radikal kaum teknokrat liberal untuk membiarkan begitu saja industri dalam negeri tidak bisa diterima sebagai dasar pembentukan kebijakan.

Sudah menjadi tantangan sejak awal bagaimana mengakomodasi kepentingan industri dalam negeri bersamaan dengan produk hukum bidang investasi asing yang sangat membatasi peranan negara sekaligus bersifat kurang menguntungkan bagi keberadaan industri dalam negeri. Keberpihakan terhadap industri dalam negeri sangatlah terbatas dalam UU PMDN yang hanya bisa di akses oleh industri dalam negeri bermodal besar. Sebagai contoh, dalam UU tersebut industri dalam negeri yang ingin memperoleh akses dan fasilitas khusus yang di 
tawarkan UU PMDN wajib menaruh deposito kepada bank negara sebanyak $25 \%$ dari invetasi mereka pada bidang-bidang prioritas dan 50\% pada bidang yang bukan prioritas. Akibat dari keterbatasan itu ialah hanya industri bermodal besar-lah yang bisa memperoleh akses atas fasilitas UU PMDN. Mereka berasal dari golongan Tionghoa dan beberapa pengusaha sipil yang memiliki jaringan bisnis internasional dan telah menyimpan dana mereka di luar negeri sejak rezim ekonomi terpimpin. Praktis dengan sendirinya kemampuan mereka atas alokasi sumber daya tidak bisa di abaikan begitu saja. Melalui Pasal 9 UU PMDN Pemerintah menawarkan fasilitas pemutihan modal yang menyatakan bahwa modal itu dapat kembali ke Indonesia dan dijamin secara hukum hak kepemilikannya tanpa ada keharusan di pihak pemiliknya untuk menjelaskan asal-usulnya atau untuk membuktikan bahwa pajaknya telah dilunasi. Melalui UU PMDN banyak para industrialis tadi mengadakan hubungan patron klien untuk memperoleh lisensi tertentu, monopoli impor, kemudahan joint venture dan sebagainya (Muhaimin, 1990; Robison dan Hadiz, 2004; Chua, 2008; Iswandi 1998 dan; Couch, 2007). Dengan mencermati perkembangan para industrialis dalam negeri yang memperoleh proteksi melalui UU PMDN, pandangan bahwa setiap kebijakan industri yang dibuat rezim Orde Baru semata-mata mencerminkan kepentingan investasi asing tidaklah tepat.

Namun demikian, berbagai kebijakan industri dan perlindungan hukum yang selama ini telah diberikan Orde Baru kepada investasi asing dan kepentingan industri dalam negeri tertentu-walaupun berhasil mengembalikan keadaan ekonomi lebih baik-pada nyatanya telah menimbulkan dampak negatif bagi kelangsungan kekuasaan rezim. Mereka yang selama ini-yang terdiri dari kalangan mahasiswa, pengusaha kecil, cendikiawan nasionalis, bahkan kaum miskin-yang telah menjadi pendukung koalisi kekuasaan Orde Baru kian tidak bisa merasakan manfaat dari capaian pertumbuhan ekonomi yang diagungkan. Para prajurit, perwira rendahan yang akrab dengan kehidupan kaum miskin, mulai tidak menyukai perilaku para Jenderal yang mencampuri urusan non-militer dan memperkaya diri sendiri (Couch dan Caldwell, 2011: 316). Kaum teknokrat nasionalis seperti Ali Murtopo, Slamet Bratanata dan A.R. Soehoed mensuarakan pandangan-pandangan alternatif dengan harapan pikiran mereka bisa di pertimbangkan dalam pembentukan kebijakan. Sepanjang awal tahun 1970an, protesprotes kecil mulai bermunculan yang mencerminkan ketidakpuasan massa terhadap berbagai kebijakan yang berpihak pada borjuasi besar.

Puncak akumulasi kekesalan tersebut pecah dalam kerusahan pada bulan Januari 1974 di pusat-pusat bisnis di Ibukota. Sekalipun peristiwa Malari bersifat simbolik dalam konteks 
perlawanan kaum intelektual dan mahasiswa terhadap dominasi modal asing, sasaran utama kemarahan mereka sebetulnya ditujukan kepada industri Jepang yang menguasai bidang usaha yang sama-sama ditekuni pengusaha pribumi Indonesia. Pada saat yang bersamaan, industriindustri milik Tionghoa turut menjadi sasaran amuk massa dan berubah menjadi sentimen rasialis terhadap etnis Tionghoa di Indonesia. Pada tataran kebijakan, perisitiwa tersebut bersifat fundamental dalam arti secara radikal mengubah pendulum kebijakan industri menjadi lebih proteksionis. Pikiran alternatif kaum teknokrat nasionalis mulai dipertimbangkan agar Pemerintah bisa mengakomodasi tuntutan pengusaha kecil yang tengah merosot agar diberikan proteksi untuk menghadapi persaingan industri modal asing yang unggul, terlebih tuntutan untuk menyingkirkan hambatan politik dan ekonomi terhadap potensi mereka untuk berkembang (Robison, 2012: 114). Setelah peristiwa Malari 1974 Pemerintah telah mengurangi pengaruh kaum teknokrat liberal dan memberi kesempatan kepada teknokrat nasionalis untuk merumuskan kebijakan yang bisa memuaskan semua pihak.

Salah satu unsur yang harus dipertimbangkan dalam melihat pergeseran pendulum kebijakan industri adalah peningkatan pendapatan negara atas sektor minyak akibat melonjaknya harga minyak dunia. Kemampuan belanja negara dan peningkatan produktivitas perusahaan negara pada tahun 70an telah mengakibatkan peranan negara atas perekonomian kini jauh lebih besar ketimbang pada masa sebelumnya. Dalam Repelita II dan III sektor migas telah ditempatkan sebagai sektor strategis yang harus diperluas pada bidang usaha energi lain untuk menggandakan pendapatan negara. Karena itu dalam rangka memperluas kemampuan akumulasi perusahaan migas negara selama tahun 1970an, Pertamina dan Pemerintah sama-sama mencari pinjaman hutang baru di luar negeri baik melalui IGGI atau pihak lain.

Kebangkitan kelompok teknokrat nasionalis juga dapat dilacak pada awal tahun 1970an melalui keterlibatan mereka sebagai panitia perancang RUU Pertamina. Keberhasilan Ibnu Sutowo membawa Pertamina sebagai industri migas paling penting dalam pembangunan rezim Orde Baru, membuat Soeharto merasa bahwa pikiran-pikiran nasionalistis (yang pada nyatanya sangat menguntungkan para pemburu rente) patut diperhitungkan. Karenanya ia sendiri memerintahkan Ibnu Sutowo untuk melibatkan teknolog-teknolog penting dalam imperium Pertamina, seperti B.J. Habibie yang saat itu bekerja di Jerman untuk sebuah perusahaan kapal terbang. Sinyal kebangkitan teknokrat nasionalis pula bisa dilihat dari posisi vital Ali Murtopo sebagai loyalis dan ideolog kepercayaan Soeharto yang lewat bukunya 
Akselerasi Modernisasi Pembangunan 25 Tahun yangmenyatakan bahwa ABRI adalah katalisator bagi pembangunan khususnya dalam menciptakan stabilitas dan keamanan (Murtopo, 1972). Stabilitas dan keamanan adalah penting untuk menjamin putusan-putusan yang dibuat penguasa bisa efektif. Pemikiran-pemikiran Ali Murtopo-lah, yang melegitimasi kalangan ABRI terlibat aktif hampir dalam seluruh kegiatan perekonomian negara.

Memasuki tahun 1980an, perekonomian global memperlihatkan tanda-tanda penurunan harga minyak secara mengejutkan. Kaum teknokrat liberal mengkiritk bahwa besarnya ketergantungan Pemerintah atas sektor migas membuat Pemerintah terlena dan enggan mencari alternatif pendapatan di luar sektor migas. Selain itu secara umum pada awal dekade 80an Indonesia mengalami penurunan ekspor akibat industri dalam negeri tidak bersikap responsif terhadap revolusi teknologi yang sedang terjadi. Bahwa integrasi ekonomi dunia-yang kemudian hari dikenal dengan istilah globalisasi-telah membuat banyak industri di negara lain berlomba mengefisienkan dan mengoptimalkan kegiatan usahanya, tidak membuat para industrialis dalam negeri tergugah ikut berbenah dari dalam yang membuat produk-produk mereka kurang begitu diminati di pasar dunia. Sebagaimana dinyatakan Jeffrey Winters (1999: 229):

Gambaran umum yang terjadi pada masa boom minyak adalah adanya kendala nyata pada penentu kebijakan untuk menciptakan dan memelihara iklim investasi yang kompetitif, dan responsif sebagai cara untuk menjamin pasokan investasi yang cukup di masyarakat. Sumber pendapatan negara yang didasarkan atas keuntungan luar biasa dari penjualan bahan bakar fosil telah membuat para penentu kebijakan bersikap tak acuh terhadap permohonan kebijakan para pemilik modal asing karena penurunan investasi mereka tidak merusak perekonomian secara umum. Penyusutan sumber pendapatan negara pada tahun 1980an memulihkan kembali pengaruh investasi asing dalam perekonomian nasional.

Setelah kejatuhan harga minyak pada awal tahun 1980an, para teknokrat telah memperdebatkan kemana arah kebijakan industri Orde Baru seharusnya. Kaum teknokrat liberal melihat kegiatan produktivitas dan efisiensi kegiatan usaha di Indonesia terus menurun lantaran intervensi itu justru mengakibatkan kegiatan pasar terdistorsi dan menimbulkan highcost economy. Dibawah rezim proteksionis setelah 1974, masalah yang dihadapi para pelaku pasar (terutama dari luar) adalah biaya-biaya yang tinggi, bahaya birokratisme, dan ketidakpastian akan perlindungan hukum. Radius Prawiro mengomentari kecenderungan nasionalisme ekonomi tahun 70an sebagai berikut (Prawiro, 1999: 229):

Dengan nasionalisme yang dibiayai oleh minyak, dari tahun 1974 sampai dengan 1978, kebijakan-kebijakan perdagangan, perindustrian, investasi dan keuangan 
Indonesia semau terlhat berpadu secara harmonis satu sama lain-dalam sebuah paduan yang tidak baik - untuk mendukung kebijakan yang paling berorientasi ke dalam selama sejarah Orde Baru. Kebijakan-kebijakan industri dan perdagangan Indonesia bukan saja memberi perlindungan kepada usaha-usaha yang tidak efisien dalam melayani pasar dalam negeri, tetapi kebijakan-kebijakan investasi asing negara juga mematahkan semangat para investor baru kecuali yang paling gigih ... pragmatisme ekonomi yang merupakan ciri khas manajemen ekonomi Indonesia, berada pada titik nadir. Ketika uang minyak mulai mengering, yang masih tersisa bagi Indonesia tinggallah landasan rapuh dalam industri-industri ekspor dan hubungan perdagangan yang kurang berkembang dengan negara lain.

Para teknokrat liberal meyakini kebijakan industri yang selama ini dikeluarkan Pemerintah telah mengekang para industrialis dalam negeri yang efisien dan produktif dan menghambat mekanisme pasar untuk berkembang pesat. Salah satu aspek terburuk dari kecenderungan serba mengatur bisa dilihat dari pemberian perlakuan khusus kepada banyak industri besar yang memiliki hubungan dekat dengan kekuasaan (Mallaranggeng, 2008: 116). Akan gantinya, aturan-aturan hukum harus dibuat sedemikian rupa untuk memfasilitasi semua pelaku usaha tanpa anasir-anasir kepentingan politik yang melatarbelakanginya. Hal yang sama juga dinyatakan Ali Wardhana (Wardana dalam Chalmers dan Hadiz, 2000: 119):

The decline of oil prices was a signal, clear to all, that Indonesia needed drastic measures, first to stablise the economy and prevent a downward spiral of incomes; and then to find new sources of income growth. So when the budget was cut and reform were begun, we enjoyed a broader measure of public support that governments did in many other countries under similar circumstances.

Kaum teknokrat liberal telah memperingatkan Pemerintah sejak awal mengenai rapuhnya kebijakan industri nasionalis yang sekian lama telah ditunggangi kepentingankepentingan bisnis yang merusak struktur ekonomi Indonesia. Kegagalan kebijakan industri dalam negeri bersamaan dengan krisis harga minyak membuat kaum teknokrat liberal menemukan kembali keyakinan lama mereka - atau dalam ungkapan Radius Prawiro, to rediscover the wisdom of the market (Mallaranggeng 2008: 112). Baik teknokrat liberal maupun nasionalis sama-sama mensepakati bahwa pokok permasalahan mengenai rapuhnya industri dalam negeri adalah bahwa Pemerintah tidak memiliki arah cukup jelas dalam melaksanakan strategi industrialisasi yang direncakanan. Ketiadaan rumusan yang jelas itu menyebabkan berbagai macam kepentingan politik senantiasa melatarbelakangi berbagai produk hukum yang berkaitan dengan industrialisasi. Dengan menyampaikan proposal mengenai strategi orientasi ekspor, kelompok teknokrat liberal menginginkan deregulasi 
besar-besaran yang memungkinkan para pemilik modal — baik domestik atau internasional— sebebasnya mengalokasikan modalnya tanpa campur tangan Pemerintah. Sedangkan proposal strategi orientasi ekspor dari kelompok teknokrat nasionalis menginginkan adanya penguatan struktur industri nasional dan pembatasan arus modal asing yang menurut mereka untuk sektor-sektor perekonomian penting. Melalui pengaruhnya yang cukup kuat di kursi-kursi Pemerintahan, pikiran-pikiran kaum teknokrat nasionalis berpotensi besar direalisasikan ketika Pemerintah menyadari pentingnya membentuk suatu perundang-undangan yang ditujukan untuk memperjelas arah industrialisasi nasional.

Para teknokrat nasionalis memahami apa yang mereka kenal dengan nasionalisme ekonomi dengan cara yang berbeda. Ginanjar Kartasasmita (Kepala Bappenas 1978 - 1983) menyatakan bahwa liberalisasi ekonomi itu sendiri menuntun perekonomian Indonesia kepada konsentrasi kekuasaan ekonomi disegelintir kelompok (Robison dan Hadiz, 2004: 89). Bagi Ginanjar Kartasasmita tantangan terbesar yang dihadapi Indonesia setelah kejatuhan harga minyak adalah bagaimana meningkatkan produktivitas dan efisiensi industri dalam negeri sekaligus meningkatkan peran serta masyarakat (Kartasasmita, 1996: 127). Kaum teknokrat nasionalis memang mengakui bahwa berbagai macam peraturan perundang-undangan pada awal kekuasaan Orde Baru dan praktik kebijakan industri setelah peristiwa Malari 1974 yang dibuat Pemerintah sendiri mempunyai andil cukup besar bagi terciptanya monopoli dan oligopoli industri di Indonesia (Lubis, 1985: 51). Kritik yang lebih keras juga datang dari Menteri Perindustrian tahun 1978 - 1983, A.R. Soehoed yang berangkat perspektif teori ketergantungan bahwa pertumbuhan industri yang cepat yang menjadi sasaran Repelita hanya menggeser bidang ketergantungan, dari ketergantungan terhadap barang konsumsi impor menuju ketergantungan yang lebih parah, yaitu terhadap impor bahan baku, bahan setengah jadi,komponen dan barang modal (Chalmers, 1996: 253). Dengan mengakarnya kepercayaan rezim Orde Baru terhadap kemampuan sebuah hukum sebagai sarana pembangunan ekonomi, maka pembentukan suatu perundang-undangan untuk memperjelas arah industrialisasi nasional adalah sebuah hal yang tak terelakkan.

\section{Terbentuknya UU Perindustrian dan Arah Politik Hukumnya}

Pada tahun 1979 A.R. Soehoed telah mengambil inisiatif membentuk RUU tentang Perindustrian yang akan menjadi dasar hukum bagi segala macam kegiatan industri di Indonesia (Soehoed, 2000). Momentum itu ia ambil bertepatan dengan masih tingginya 
pendapatan negara dari sektor migas dengan tujuan RUU tersebut akan mampu membiayai pembangunan industri nasional yang disalurkan dari pendapatan negara dari sektor migas. Para teknokrat nasionalis telah melihat kesalahan Pemerintah yang selama beberapa dekade terakhir hanya berfokus pada industri-industri berteknologi rendah pada sektor pertanian dan sektor pertambangan migas. Kurangnya perhatian terhadap sektor diluar keduanya menurut para teknokrat nasionalis berhasil melemahkan kemampuan industri-industri tadi dalam mencetak keuntungan. Tidak adanya satu instrumen hukum oleh Pemerintah untuk mengintegrasikan semua industri-industri tersebut yang menyebabkan persaingan antar industri. Maka dengan sendirinya bagi kalangan teknokrat naisonalis, Pemerintah justru membiarkan free fight liberalism terjadi.

Menurut Ian Chalmers, A.R. Soehoed mencita-citakan sebuah regulasi yang memungkinkan peningkatan tahap industrialisasi dari industrialisasi berteknologi rendah menuju industrialisasi berteknologi maju (Chalmers, 1996: 251). Meski mengakui kebutuhan akan keahlian bangsa asing, A.R. Soehoed mendukung pembatasan negara terhadap investasi asing, terutama untuk menghindari ketergantungan terhadap suatu sumber teknologi. Usulan A.R. Soehoed yang ambisius meniscayakan peran negara dalam menentukan alokasi sumber daya yang besar untuk mendorong ekspansi modal nasional lebih luas dan merata.

Government participation can have a variety of purposes, so it is necessary to clearly identify that purpose and ensure that participation is truly beneficial to the national development effort and [does] not slide into etatism. It must be emphasised at this point that the role of the government in the economy should extend to all economic activities, but should be restricted to a level at which it can exercie sufficient influence over the development of the national economy and have controlling intersets in those sectors and areas where national private enterprise is not-or is not yet-sufficiently strong to safeguard its interests. It is not even necessary for the government to become involved $n$ all aspects of those sectors earmarked for priority; it is sufficient for the government to limit its involement to those elements it considers vital for the success of strategy pertaining to that sector. (Soehoed dalam Chalmers dan Hadiz, 2000: 72).

Bahwa perkembangan ilmu pengetahuan dan teknologi adalah prasyarat mutlak untuk menaikkan level kemampuan teknologi industri nasional membuat A.R. Soehoed merasa penting untuk melibatkan B.J. Habibie (Menteri Riset dan Teknologi). Perlunya transformasi radikal untuk mengubah wajah industri Indonesia menjadi industri yang menggunakan teknologi maju adalah salah satu tujuan dalam RUU Perindustrian. Lewat perspektif determinisme teknologi, Habibie mengemukakakan kesediaannya menuntun Indonesia 
menjadi poros industri di Asia lewat program-program pengembangan ilmu pengetahuan dan teknologi yang disponsori Pemerintah.

Pada bulan Juni 1984, RUU Perindustrian disahkan. Sebagai produk turunan Pasal 33 UUD 1945, UU Perindustrian adalah upaya sungguh-sungguh menafsirkan subtansi konstitusi ekonomi sesuai dengan kebutuhan zaman. Dengan meletakkan UU Perindustrian dalam prospek pembangunan jangka panjang, keberadaan UU Perindustrian amat penting untuk melakukan perubahan fundamental atas struktur industri nasional. Pasal 3 menyatakan pembangunan industri nasional bertujuan untuk:

1. Meningkatkan kemakmuran dan kesejahteraan rakyat secara adil dan merata dengan memanfaatkan dana, sumber daya alam, dan/atau hasil budidaya serta dengan memperhatikan keseimbangan dan kelestarian lingkungan hidup;

2. Meningkatkan pertumbuhan ekonomi secara bertahap, mengubah struktur perekonomian ke arah yang lebih baik, maju, sehat dan lebih luas bagi pertumbuhan ekonomi pada umumnya, serta memberikan nilai tambah bagi pertumbuhan industri pada khususnya;

3. Meningkatkan kemampuan dan penguasaan serta mendorong terciptanya teknologi yang tepat guna dan menumbuhkan kepercayaan terhadap kemampuan dunia usaha nasional;

4. Meningkatkan keikutsertaan masyarakat dan kemampuan golongan ekonomi lemah, termasuk pengrajin agar berperan secara aktif dalam pembangunan industri;

5. Memperluas dan memeratakan kesempatan kerja dan kesempatan berusah, serta meningkatkan peranan koperasi industri;

6. Meningkatkan penerimaan devisa melalui peningkatan ekspor hasil produksi nasional yang bermutu, disamping penghematan devisa melalui pengutamaan pemakaian hasil produksi dalam negeri, guna mengurangi ketergantungan kepada luar negeri;

7. Mengembangkan pusat-pusat pertumbuhan industri yang menunjang pembangunan daerh dalam rangka perwujudan wawasan nusantara;

8. Menunjang dan memperkuat stabilitas nasional yang dinamis dalam rangka memperkokoh ketahanan nasional.

Harus di akui UU Perindustrian mencoba mengarahkan arah pembangunan nasional lebih merata dan berkeadilan. Bagi para teknokrat nasionalis, UU Perindustrian merupakan jawaban bagi ketidakjelasan strategi industrialisasi nasional. Setidaknya terdapat empat arah politik hukum yang diperlihatkan UU Perindustrian. Pertama, perluasan kesempatan bagi industri nasional dalam mengembangkan kegiatan usahanya. UU Perindustrian mengamanatkan Pemerintah menyediakan keadaan dan memfasilitasi industri dalam negeri dalam bersaing dengan modal asing. Melalui strategi industrialisasi orientasi ekspor yang jelas, industri nasional diarahkan untuk melakukan kegiatan ekspor yang akan meningkatkan pendapatan devisa nasional. Sebagaimana dinyatakan penjelasan UU Perindustrian: 
Pelaksanaan pembangunan sekaligus harus menjamin pembagian pendapatan yang merata bagi seluruh rakyat sesuai dengan rasa keadilan, dalam rangka mewujudkan keadilan sosial sehingga di satu pihak pembangunan itu tidak hanya ditujukan untuk meningkatkan produksi, melainkan sekaligus mencegah melebarnya jurang pemisah antara kaya dan yang miskin. Dnegan memperhatikan sasaran pembangunan jangka panjang di bidang ekonomi tersebut, maka pembangunan industri memiliki peranan yang sangat penting. Dengan arah dan sasaran tersebut, pembangunan industri bukan saja berarti harus semakin ditingkatkan dan pertumbuhannya dipercepat sehingga mampu menpercepat terciptanya struktur ekonomi yang lebih seimbang, tetapi pelaksanaannya harus pula makin mampu memperluas kesempatan kerja, meningkatkan rangkaian proses produksi inudstri untuk memenuhi kebutuhan dalam negeri sehingga mengurangi ketergantungan terhadap impor dan meningkatkan ekspor hasil industri itu sendiri.

Kedua, penciptaan kondisi yang memungkinkan Pemerintah berkewenangan mengembangkan ilmu pengetahuan dan teknologi untuk industri nasional. Berbagai macam klausul teknologi dapat dikatakan mencerminkan pikiran-pikiran B.J. Habibie tentang tahaptahap industrialisasi (Habibie, 1986). Ketiga, penciptaaan iklim investasi dalam negeri yang kondusif bagi semua pelaku ekonomi, baik perusahaan negara, swasta besar, menengah dan koperasi. Menurut A.R. Soehoed dengan melibatkan semua pelaku ekonomi dalam kegiatan industri nasional, secara bertahap akan mengintegrasikan berbagai macam pelaku ekonomi dalam sistem industri yang sistematis (Kian Wie, 1994: 22). Keempat, reorganisasi struktur kepemilikan modal dalam negeri demi mencegah Indonesia terjebak dalam ketergantungan modal asing lebih dalam. Hal ini diwujudkan dengan banyak pasal UU Perindustrian yang memberikan perlindungan serta perlakuan khsus kepada industri nasional seperti melakukan pengaturan, pembinaan dan pengembangan industri. Perlakuan khusus ditunjukkan misalnya oleh Pasal 5 ayat (1) yang memberikan kewenangan kepada Pemerintah untuk menentapkan bidang industri yang digeluti kelompok industri kecil yang hanya bisa di usakan oleh warga negara Indonesia. Selain itu Pemerintah juga dapat memberikan kemudahan dan/atau perlindungan yang diperlukan untuk mendorong pengembangan cabang industri dan jenis industri tertentu di dalam negeri (Pasal 12).

Namun demikian, sekalipun UU Perindustrian berhasil merumuskan secara ketat strategi industrialisasi Indonesia, persoalan monopoli dan oligopoli sayangnya tidak diatur dengan baik. Tentu saja kekurangan ini merupakan kesalahan mendasar dari para pengusung UU Perindustrian. Dalam UU Perindustrian aturan mengenai monopoli dan oligopoli hanya disebutkan dalam pasal 7 ayat (3) yang menyatakan: 'pemerintah mencegah pemusatan atau 
penguasaan industri oleh satu kelompok atau perorangan dalam bentuk monopoli yang merugikan masyarakat', dan pasal 9 ayat (2) yang menyebutkan 'pengaturan dan pembinaan bidang usaha industri dilakukan dengan penciptaan iklim yang sehat bagi pertumbuhan industri dan pencegahan persaingan yang tidak jujur antara perusahaan-perusahaan yang melakukan kegiatan industri, agar dapat dihindarkan pemusatan atau penguasaan industri oleh satu kelompok atau perorangan dalam bentuk monopoli yang merugikan masyarakat'. Absennya pengaturan monopoli dan oligopoli inilah yang menjadi celah bagi bangkitnya kekuatan oligarkiyang bercokol dalam kekuasaan rezim otoritarian Orde Baruyang berhasil mereorganisasikan diri di tengah gelombang reformasi neoliberal pasca Soeharto (Robison dan Hadiz, 2004).

\section{KESIMPULAN}

Kemunculan UU Perindustrian dilatarbelakangi oleh pentingnya sektor perindustrian sebagai arena pertarungan yang kompleks yang melibatkan berbagai kepentingan politik, pemikiran teknokrat serta berbagai kepentingan bisnis. Kendati sektor ini bukanlah sektor utama yang menjadi mata pencaharian rakyat Indonesia seperti halnya sektor pertanian, sokongannya terhadap pertumbuhan ekonomi dan pencapaian kesejahteraan tidak bisa abaikan. Dengan semakin strategisnya perkembangan industri di Indonesia di satu pihak dan semakin kompetitifnya industri negara satu dengan yang lain, maka sangatlah penting bagi negara menyediakan landasan hukum yang mampu memberikan perlindungan bagi industri dalam negeri. Oleh karenanya arah politik hukum UU Perindustrian adalah menciptakan kondisi-kondisi yang memungkinkan industri dalam negeri dapat mandiri dalam memperluas kegiatan industrinya serta mengurangi ketergantungan Indonesia akan investasi asing.

\section{REFERENCES}

Anggoro, Syahriza Alkohir, (2019) Politik Hukum: Mencari Sejumlah Penjelasan, dalam Jurnal Cakrawala Hukum, Vol 10 No 1

Chalmers, Ian dan Vedi R. Hadiz, (2000), The Politics ofEconomic Development in Indonesia, London: Routledge

Chalmers, Ian, (1996), The Political Economy of Indonesian Automotive Industry, diterjemahkan oleh Mien Joebhaar, Konglomerasi: Negara dan Modal dalam Industri Otomotif Indonesia 1950 - 1985, Jakarta: Penerbit Gramedia 
Chua, Christian, (2008), Chinese Big Business in Indonesia, New York: Routledge

Couch, Harold, (2007), The Army and Politics in Indonesia, Singapore: Exuinox Publishing

Habibie,B.J.,(1986),Strategi Transformasi Industri Suatu Negara Sedang Berkembang, Jakarta: Gema Insani Press

Hadiz, Vedi R., (2005)Dinamika Kekuasaan Ekonomi Politik Pasca Soeharto, Jakarta: LP3ES

Hatta, Mohammad, (1980),Membangun Koperasi dan Koperasi Membangun, Jakarta: Inti Idayu Press, 1980

Iswandi, (1998), Bisnis Militer Orde Baru Keterlibatan ABRI dalam Bidang ekonomi dan Pengaruhnya terhadap Pembentukan Rezim Otoriter, Bandung: PT Remajarosdakarya

Kartasasmita, Ginanjar, (1996), Pembangunan Untuk Rakyat Memadukan Pertumbuhan dan Pemerataan, Jakarta: CIDES

Kian Wie, Thee, (1994),Industrialisasi di Indonesia: Beberapa Kajian, Jakarta: LP3ES

Kian Wie, Thee, (2012), Indonesia's Economy Since Independence, Singapore: ISEAS Publishing

Lev, Daniel S., (1966),Transition to Guided Democracy 1957 - 1959, Ithaca: Cornell University Press

Mahfud MD, (1995),Konfigurasi Politik dan Karakter Produk Hukum, dalam Jurnal Prisma No 7

Mallaranggeng, Rizal, (2008), Mendobrak Sentralisme Ekonomi Indonesia 1986 - 1992, Jakarta: KPG, 2008

Mattei, Ugo dan John D. Haskell (ed.), (2015), Research Handbook on Political Economy and Law, Cheltenham: Edward Elgar Publishing Limited

Muhaimin, Yahya, (1990),Bisnis dan Politik di Indonesia Kebijaksanaan ekonomi Indonesia 1950 - 1980, Jakarta: LP3ES

Mulya Lubis, Todung, (1985), Monopoli dan Oligopoli dalam Tinjauan Hukum, dalam Jurnal Prisma Elite, Monopoli dan Oligopoli Edisi No 2

Murtopo, Ali, (1972), Dasar-dasar Pemikiran tentang Akselerasi Modernisasi Pembangunan 25 Tahun, Jakarta: CSIS 
Prawiro, Radius, (1999),Pergulatan Indonesia Membangun Ekonomi Pragmatisme dalam Aksi, Jakarta: Elexmedia

Robison, Richard dan Vedi R. Hadiz, (2004)Reorganising Power in Indonesia the Politics of Oligarchy in the Age of Market, New York: Routledge

Robison, Richard, The Rise of Capital, diterjemahkan oleh Harsutejo, Soeharto dan Bangkitnya Kapitalisme Indonesia, Jakarta: Komunitas Bambu, 2012

SoehoedA.R., (2000)Asahan Peluang yang Bisa Terbuang, Jakarta: Sinar Harapan

Utrecht, Ernst dan Malcolm Caldwell, (2011), Indonesia: An Alternative History, terjemahan oleh Saut Pasaribu, Sejarah Alternatif Indonesia, Yogyakarta: Penerbit Djaman Baroe dan Sajogyo Insitute

Wignjosoebroto,Soetandyo, (2013)Hukum, Konsep dan Metode, Malang: Setara Press

Wignjosoebroto, Soetandyo, (2014), Dari Hukum Kolonial ke Hukum Nasional, Jakarta: HuMa, Van Vollenhoven, KITLV-Jakarta dan Epistema Institute

Winters, Jeffrey, (1999),Power in Motion: Capital Mobility and the Indonesia State, Tanpa Penerjemah, Power in Motion Modal Berpindah Modal Berkuasa Mobilitas Investasi dan Politik di Indonesia, Jakarta: Sinar Harapan

Yamin, Muhammad, (1959)Naskah Persiapan Undang-Undang Dasar 1945 Jilid 1, tanpa lokasi: Penerbit Jajasan Prapantja 